\title{
The Rationality of Antibiotic Use on Patients of Typhoid Fever
}

\author{
Rasionalitas Penggunaan Antibiotik pada Pasien Demam Tifoid
}

\author{
Riefki Indira Hudi ${ }^{1}$, Imaniar Ranti ${ }^{2 *}$ \\ ${ }^{1}$ Faculty of Medicine and Health Sciences, Universitas Muhammadiyah Yogyakarta, Jalan Brawijaya, Tamantirto, Kasihan, \\ Bantul, Special Region of Yogyakarta, Indonesia. \\ 2 Department of Pharmacology, Faculty of Medicine and Health Sciences, Universitas Muhammadiyah Yogyakarta, Jalan \\ Brawijaya, Tamantirto, Kasihan, Bantul, Special Region of Yogyakarta, Indonesia.
}

DATA OF ARTICLE:

Received: 27 Jun 2019

Reviewed: 18 Jul 2019

Revised: 8 Nov 2019

Accepted: 25 Nov 2019

\section{*CORRESPONDENCE:}

imaniarranti@umy.ac.id

DOI:

10.18196/mm.200133

TYPE OF ARTICLE:

Research

\begin{abstract}
Typhoid fever is an infectious disease caused by Salmonella typhi bacteria. The administration of antibiotics in typhoid fever is needed as a causative therapy to eradicate the bacteria based on the principles of rational therapy to avoid antibiotic resistance. However, there are still a considerable amount of cases of unnecessary antibiotic administration. This study aims to examine the rationality of antibiotic use on patients of typhoid fever. This research is a non-intervention study with descriptive analytic methods. Data were retrieved retrospectively by identifying the medical records of patients treated in the X Hospital Salatiga from January to August 2016 with a purposive sampling method based on the inclusion and exclusion criteria of 67 cases. The data was analyzed by using Gyssen criteria based on the standard of typhoid fever service of WHO 2011. The result showed that the percentage of female typhoid fever patients was higher than the male with the most prolonged 3-day hospitality. The most commonly used antibiotics are ceftriaxone, ciprofloxacin, and cefixime with the result of the rationality analysis of category 0 (55.22 \%), category IIIA (1.49\%), category IIIB ( 8.96\%), category IVA (17.91\%), and category IVC (4.48\%). It can be concluded that the rationality of antibiotics used in patients with typhoid fever at X Hospital Salatiga based on Gyssen criteria showed a good result.
\end{abstract}

Keywords: Antibiotics; Gyssen criteria; Rationality; Typhoid fever

Abstrak: Demam tifoid merupakan penyakit infeksi yang disebabkan oleh bakteri Salmonella typhi. Pemberian antibiotik pada demam tifoid diperlukan sebagai terapi kausatif untuk mengeradikasi bakteri penyebab sesuai dengan prinsip terapi rasional untuk menghindari resistensi antibiotik. Namun masih banyak kasus pemberian antibiotik yang sebenarnya tidak diperlukan. Penelitian ini bertujuan untuk mengkaji rasionalitas penggunaan antibiotik pada pasien demam tifoid. Jenis penelitian ini adalah penelitian nonintervensi dengan metode deskriptif analitik. Data diambil secara retrospektif dengan melihat rekam medis pasien yang dirawat di Rumah Sakit X Salatiga periode Januari - Agustus 2016 dengan metode purposive sampling sesuai dengan kriteria inklusi dan eksklusi sebanyak 67 kasus. Analisis data menggunakan kriteria Gyssen sesuai standar pelayanan demam tifoid menurut WHO 2011. Hasil penelitian menunjukkan pasien demam tifoid perempuan lebih banyak daripada laki-laki dengan lama rawat inap terbanyak selama 3 hari. Antibiotik yang sering digunakan yaitu ceftriaxone, ciprofloxacin, dan cefixime dengan hasil analisis rasionalitas kategori 0 (55,22\%), kategori IIIA (1,49\%), kategori IIIB (8,96\%), kategori IVA (17,91\%), dan kategori IVC (4,48\%). Disimpulkan bahwa rasionalitas penggunaan antibiotik pada pasien demam tifoid di Rumah Sakit X Salatiga Tahun 2016 menurut kriteria Gyssen menunjukkan hasil baik.

Kata Kunci: Antibiotik; Kriteria Gyssen; Rasionalitas; Demam tifoid 


\section{INTRODUCTION}

Antibiotics are chemicals that can inhibit growth or kill microorganisms. ${ }^{1}$ Excessive and inappropriate use of antibiotics reaches $20-50 \%$ of all antibiotics used in the world. The Center for Disease Control and Prevention (CDC) in the United States estimates that around 50 million out of 150 million antibiotics are unnecessary. ${ }^{2} \mathrm{~A}$ total of $13 \%$ to $37 \%$ of all patients hospitalized in developed countries obtain either single or combination antibiotics, while the use in developing countries reaches $30-80 \%{ }^{3}$

One of the health problems that need to be treated with antibiotics is typhoid fever. Typhoid fever is an infectious disease caused by Salmonella typhi bacteria. The incidence of typhoid fever is still estimated to be high at around 17 million per year and also is considered to be the cause of 222,000 deaths per year. ${ }^{4}$ Clinical symptoms of typhoid fever start from the mildest, such as fever and gastrointestinal disorders to severe complications such as seizures, encephalopathy, or intestinal bleeding. Therefore, a good treatment of typhoid fever is highly important. ${ }^{5}$ The administration of antibiotics in typhoid fever is required as a causative therapy to eradicate the bacteria based on the principles of rational therapy.

It requires rules and clear instructions in the use of antibiotics on an ongoing basis, as well as a control system to increase the level of rationality of antibiotic use. The rationality of antibiotic use, according to Gyssen's criteria, includes precise indications, efficacious, safe, and affordable costs. The rationality in the use of antibiotics can prevent bacterial resistance whose main purpose is to reduce morbidity and mortality due to the use of antibiotics in patients, save treatment costs, shorten hospitality, save hospital operating costs and improve hospital service quality. ${ }^{6}$

Based on the explanation above, it is necessary to examine the level of rationality of antibiotic use in patients of typhoid fever as a process of evaluation and control system of antibiotic use in hospitals.

\section{MATERIALS AND METHOD}

This research is a non-intervention study with descriptive analytic methods. Data were collected retrospectively by identifying the medical records of patients treated in the Internal Medicine Ward of $X$ Hospital Salatiga with a purposive sampling method.

The inclusion criteria for sampling were the medical records of patients diagnosed with typhoid fever from January 2016 to August 2019 with the complete data of antibiotic use, including the type of drug, duration of administration, dose, frequency of administration, and the route of administration. The exclusion criteria of this study were medical records of typhoid fever patients who returned home under self-demand, referenced, or passed away that the administration of antibiotics stopped, or patients with typhoid fever and other infectious diseases.

The diagnosis of typhoid fever in this study referred to the diagnosis written by the doctor in the medical record without identifying how the doctor diagnosed. The rationality of antibiotic use was later analyzed descriptively by using Gyssen's assessment criteria with the procedure showed in Figure 1. ${ }^{7}$

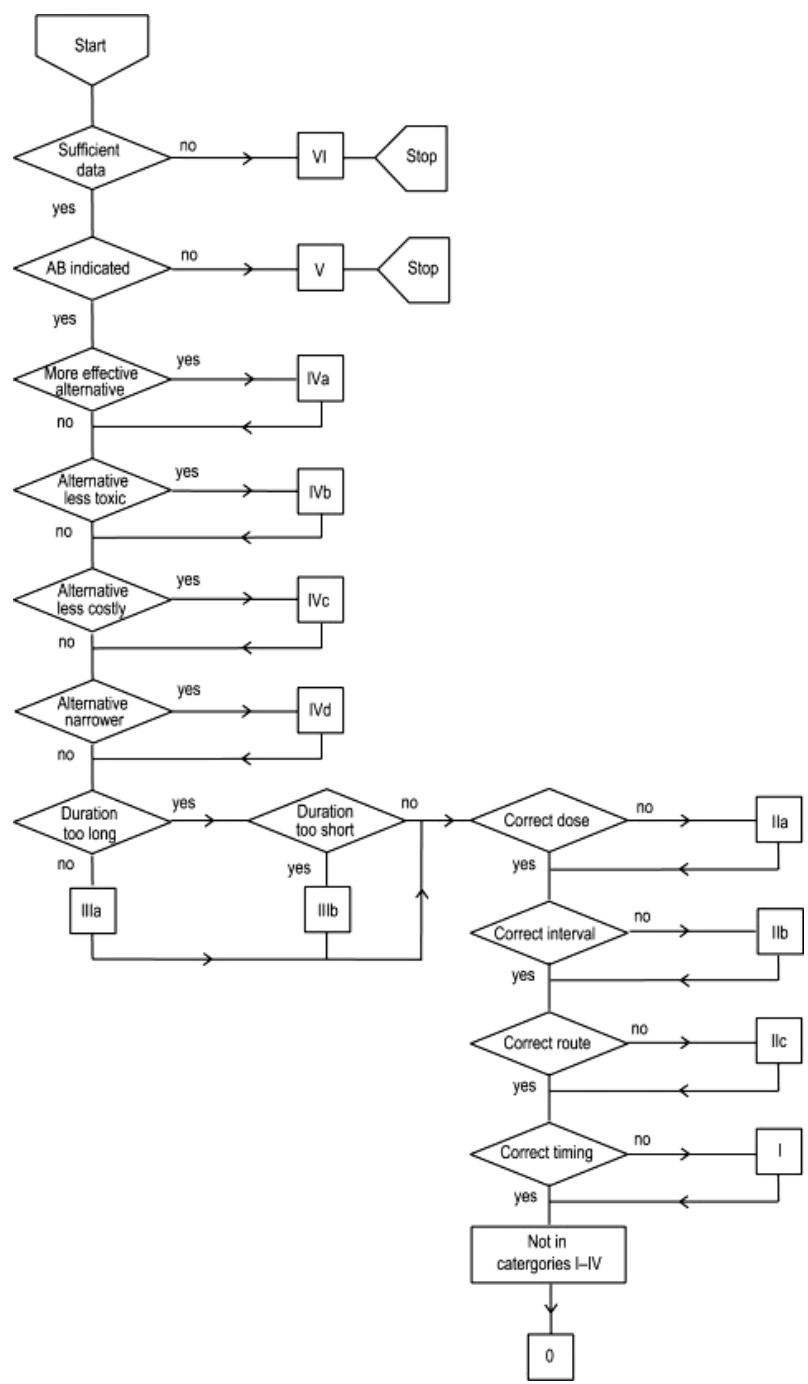

Figure 1. The flow chart of the rationality of antibiotic use based on Gyssen's criteria 


\section{RESULT}

Based on the identification of the medical records in this study, 67 medical records fitted the inclusion criteria from January 2016 to August 2019 in the Internal Medicine Ward of X Hospital Salatiga. The characteristics of the research subject in this study indicated that the prevalence of patients diagnosed with typhoid fever commonly happened more in women than men with the main fever as the main symptom and the gastrointestinal disorders as the additional symptom such as nausea, vomit, and abdominal pain. The fastest duration of treatment for typhoid fever patients in this study was two days and a maximum of seven days with three-day hospitality.

The result of the research is shown in the following table. The characteristics of the research subject are shown in Table 1. The characteristics of the use of antibiotics in patients of typhoid fever are shown in Table 2, and qualitative analysis of the rationality of the use of antibiotics in patients of typhoid fever in the Internal Medicine Ward $X$ Hospital Salatiga is shown in Table 3.

Based on Table 1, the subject was dominated by female as were $39(58.21 \%)$, by age, more than half of the sample (68.66\%) were $26-35$ years old. The clinical symptoms that most experienced was fever (89.55\%) while the most rarely experienced

Table 1. Subject Characteristics

\begin{tabular}{lcc}
\hline Characteristics & Total & Percentage \\
\hline Gender & & \\
Male & 28 & $41.79 \%$ \\
Female & 39 & $58.21 \%$ \\
Age & & \\
26-35 years old & 46 & $68.66 \%$ \\
36-45 years old & 21 & $31.34 \%$ \\
Clinical Symptoms & & \\
Fever & 60 & $89.55 \%$ \\
Nausea & 41 & $61.19 \%$ \\
Vomiting & 34 & $50.75 \%$ \\
Headache & 34 & $50.75 \%$ \\
Abdominal pain & 18 & $26.87 \%$ \\
Malaise & 11 & $16.42 \%$ \\
Myalgia & 11 & $16.42 \%$ \\
Dysphagia & 1 & $1.49 \%$ \\
Epistaxis & 1 & $1.49 \%$ \\
The duration of & & \\
hospitalization & & \\
2 days & 10 & $14.93 \%$ \\
3 days & 25 & $37.31 \%$ \\
4 days & 17 & $25.37 \%$ \\
5 days & 9 & $13.43 \%$ \\
6 days & 1 & $1.49 \%$ \\
7 days & 5 & $7.46 \%$ \\
\hline
\end{tabular}

Table 2. The characteristics of the use of antibiotics in patients of typhoid fever

\begin{tabular}{lcc}
\hline Characteristics & Total & Percentage \\
\hline Type of antibiotics & & \\
Ceftriaxone & 47 & $70.15 \%$ \\
Ciprofloxacin & 12 & $17.91 \%$ \\
Cefixime & 8 & $11.94 \%$ \\
\hline
\end{tabular}

The duration of the administration based on the type of antibiotics

$\begin{array}{llll}\text { Ceftriaxone } & 2 \text { days } & 7 & 10.45 \%\end{array}$

\begin{tabular}{llcc} 
& 3 days & 23 & $34.33 \%$ \\
& 4 days & 14 & $20.90 \%$ \\
& 5 days & 2 & $2.99 \%$ \\
& 7 days & 1 & $1.49 \%$ \\
\hline Ciprofloxacin & 4 days & 2 & $2.99 \%$ \\
& 5 days & 3 & $4.48 \%$ \\
& 6 days & 2 & $2.99 \%$ \\
\hline Cefixime & 7 days & 5 & $7.46 \%$ \\
\hline 3 days & 1 & $1.49 \%$ \\
& 5 days & 6 & $8.96 \%$ \\
& 7 days & 1 & $1.49 \%$
\end{tabular}

\begin{tabular}{lccc} 
Dose & & & \\
Ceftriaxone & $2 \mathrm{gr}$ & 47 & $70.15 \%$ \\
Ciprofloxacin & $1 \mathrm{gr}$ & 12 & $17.91 \%$ \\
Cefixime & $200 \mathrm{mg}$ & 8 & $11.94 \%$ \\
\hline
\end{tabular}

\begin{tabular}{lccc}
\multicolumn{2}{l}{ Administration Interval } & & \\
Ceftriaxone & $1 \times 2 \mathrm{gr}$ & 28 & $41.79 \%$ \\
& $2 \times 1 \mathrm{gr}$ & 19 & $28.36 \%$ \\
Ciprofloxacin & $2 \times 500 \mathrm{mg}$ & 12 & $17.91 \%$ \\
Cefixime & $2 \times 100 \mathrm{mg}$ & 8 & $11.94 \%$ \\
\hline \multicolumn{2}{l}{ Administration route } & & \\
Ceftriaxone & IV & 47 & $70.15 \%$ \\
Ciprofloxacin & Oral & 12 & $17.91 \%$ \\
Cefixime & Oral & 8 & $11.94 \%$ \\
\hline
\end{tabular}

was dysphagia and epistaxis (1.49\%). The duration of hospitalization varid between 2-7 days but most were between 2-4 days.

Based on Table 2, it showed that Ceftriaxone is the most widely used antibiotics by 47 (70.15\%) samples. The longest duration of the administration was similar in all the types of antibiotics, namely 7 days. Based on the dose, Ceftriaxone was the highest dose ( $2 \mathrm{gr}$ ) and most widely used. All the types of antibiotics administered two times a day, but Ceftriaxone is also given one times a day and intravenous route is the most common used administration route.

Based on the analysis, which is shown in Table 3, it can be identified that the use of antibiotics in patients of typhoid fever in Internal Medicine Ward in the $X$ Hospital Salatiga has a high number in category o by $55.22 \%$. The effectiveness of antibiotic selection in patients of typhoid fever showed that $17.91 \%$ of cases were in the IVA criteria 
Table 3. Rationality analysis of antibiotic use in patients of typhoid fever based on Gyssen

\begin{tabular}{|c|c|c|c|c|}
\hline \multicolumn{3}{|c|}{ Gyssen Classification } & $\begin{array}{l}\text { Total of } \\
\text { Antibiotics }\end{array}$ & Percentage \\
\hline \multicolumn{3}{|c|}{ Category 0} & 37 & $55.22 \%$ \\
\hline \multicolumn{3}{|c|}{ Category I } & - & - \\
\hline \multicolumn{3}{|c|}{ Category IIA } & - & - \\
\hline \multicolumn{3}{|c|}{ Category IIB } & - & - \\
\hline \multicolumn{3}{|c|}{ Category IIC } & - & - \\
\hline \multicolumn{3}{|c|}{ Category IIIA } & 1 & $1.49 \%$ \\
\hline \multicolumn{3}{|c|}{ Category IIIB } & 6 & $8.96 \%$ \\
\hline \multicolumn{3}{|c|}{ Category IVA } & 12 & $17.91 \%$ \\
\hline \multicolumn{3}{|c|}{ Category IVB } & - & - \\
\hline \multicolumn{3}{|c|}{ Category IVC } & 3 & $4.48 \%$ \\
\hline \multicolumn{3}{|c|}{ Category IVD } & - & - \\
\hline \multicolumn{3}{|c|}{ Category V } & - & - \\
\hline \multicolumn{3}{|c|}{ Category VI } & - & - \\
\hline \multicolumn{5}{|c|}{ Note: } \\
\hline 0 & 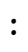 & \multicolumn{3}{|c|}{ Rational use of antibiotics } \\
\hline I & ： & \multicolumn{3}{|c|}{$\begin{array}{l}\text { Inappropriate antibiotic administration } \\
\text { period }\end{array}$} \\
\hline IIA & : & \multicolumn{3}{|c|}{$\begin{array}{l}\text { Inappropriate antibiotic administration } \\
\text { dose }\end{array}$} \\
\hline IIB & : & \multicolumn{3}{|c|}{$\begin{array}{l}\text { Inappropriate antibiotic administration } \\
\text { interval }\end{array}$} \\
\hline IIC & : & \multicolumn{3}{|c|}{$\begin{array}{l}\text { Inappropriate antibiotic administration } \\
\text { route }\end{array}$} \\
\hline IIIA & \multicolumn{4}{|c|}{ : The antibiotic use takes too long } \\
\hline IIIB & \multicolumn{4}{|c|}{ : The antibiotic use takes too short } \\
\hline IVA & \multicolumn{4}{|c|}{ : There are more effective antibiotics } \\
\hline IVB & \multicolumn{4}{|c|}{ : There are safer antibiotic alternatives } \\
\hline IVC & \multicolumn{4}{|c|}{ : There are cheaper antibiotic alternatives } \\
\hline IVD & 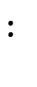 & \multicolumn{3}{|c|}{$\begin{array}{l}\text { There are alternative antibiotics with a } \\
\text { narrower spectrum }\end{array}$} \\
\hline V & & \multicolumn{3}{|c|}{$\begin{array}{l}\text { Antibiotic administration without } \\
\text { indication }\end{array}$} \\
\hline $\mathrm{VI}$ & \multicolumn{4}{|c|}{ : Incomplete data } \\
\hline
\end{tabular}

indicating that there were other more effective antibiotics. The duration of antibiotics in this study showed that $8.96 \%$ of cases shortly received antibiotic therapy (category IIIB), while another $1.49 \%$ received antibiotics in an overlong period (category IIIA). The result also showed that there were $4.48 \%$ cases (3 patients) receiving more expensive Ceftriaxone antibiotics with a patent brand compared to generic Ceftriaxone antibiotics (category IVC).

\section{DISCUSSION}

The greater number of female patients with a diagnosis of typhoid fever in this study is in line with several preliminary studies. The tendency is caused by the fact that women have a three-time greater risk of becoming a carrier or people who can remove the Salmonella typhi bacteria after a three-month infection even without showing apparent clinical symptoms. ${ }^{8,9}$ However, several other studies are stating that typhoid fever has a 3.8-time higher risk for men due to the habit of drink and food stall consumption and less attention to cleanliness. ${ }^{10,11}$

In this study, the main complaint found in the medical record data is fever. Two to seven days of fever onset characterized by the step-ladder fever in which the temperature continues to rise day to day and get worse at night is one of the typical symptoms of typhoid fever. Additional complaints such as nausea, vomiting, malaise also happened frequently to patients of typhoid fever. ${ }^{12,13}$

The use of antibiotics in typhoid fever in the Internal Medicine Ward of X Hospital Salatiga has good rationality of $55.22 \%$ (category 0 ) compared to the result of the rationality study of antibiotic use in typhoid fever patients in other hospitals which showed the rationality above and below 50\%. ${ }^{14-17}$

Based on the result of this study, it can be seen that there is $17.91 \%$ (12 patients) who previously received antibiotics Ciproflaxin and should be halted in the IVA category due to other more effective antibiotics (Table 3). ${ }^{4,7}$ It is in line with the result of Butler's research $(2011)^{18}$ stating that antibiotic Ceftriaxone is considered more effective with a cure rate of $72 \%$ compared to Ciprofloxacin, which is only $62 \%$. Furthermore, Sidabutar (2010) ${ }^{19}$ also states that the use of Ceftriaxone in typhoid fever is faster in reducing the incidence of fever and changing in culture results, and has a low risk of resistance. Ceftriaxone is a cephalosporin antibiotic, including Cefixime, which in this study was given in $11.94 \%$ of cases of typhoid fever (Table 2).

The rationality analysis of antibiotic use in terms of cost-effectiveness in this study showed that there were $4.48 \%$ of cases (Table 3 ), including in the IVC category, namely cheaper antibiotic options. Antibiotics are considered to be expensive if the price is above Rp100,000.00 each injection ampoule or each oral antibiotic strip, such as patent antibiotics prescribed to 3 patients in this study. ${ }^{20}$

The rationality analysis of the duration of antibiotic therapy in this study showed that $1.49 \%$ of cases were categorized as IIIA with an overlong duration of administration, and $8.96 \%$ of cases were categorized as IIIB with over concise duration of the administration. The duration of antibiotic administration in the case of infection is recommended to be within 5 to 7 days. It aims to eradicate the bacteria and avoid resistance altogether. ${ }^{5}$ 


\section{CONCLUSION}

The rationality of the use of antibiotics in patients of typhoid fever in the Internal Medicine Ward of the X Hospital Salatiga from January 2016 to August 2019 based on Gyssen criteria is in a good category that is $55.22 \%$.

\section{REFERENCES}

1. Dorland, W.A. Kamus Kedokteran Dorland. Ed. 28. Jakarta: EGC. 2012.

2. Bisht, R., Katiyar A., Singh R., and Mittal P. Antibiotik Resistance - A Global Issue Of Concern. Asian Journal of Pharmaceutical and Clinical Research, 2009; 2 (2): 34-39.

3. Katarnida, S.S.K., Murniati D., and Katar Y. Evaluasi Penggunaan Antibiotik Secara Kualitatif di RS Penyakit Infeksi Sulianti Saroso, Jakarta. Sari Pediatri, 2014; 15 (6): 369-376.

4. WHO. The Role of Education in the Rational Use of Medicines. WHO Library Cataloguing-inPublication data ed. 45. New Delhi, India. 2006.

5. Kemenkes R.I. Pedoman Pengendalian Demam Tifoid. Jakarta: Kementerian Kesehatan Republik Indonesia. 2006.

6. Anggraini AB, Opitasari C, and Sari QAMP. The use of antibiotics in hospitalized adult typhoid patients in an Indonesian hospital. Health Science of Indonesia. 2014; 5 (1): 40-43.

7. Gyssens, I. C. Audits for monitoring the quality of antimicrobial prescriptions. In Antibiotic Policies (pp. 197-226). Springer, Boston, MA. 2005.

8. Saraswati, N.A., and M. Ulfa. Karakteristik Tersangka Demam Tifoid Pasien Rawat Inap di RS Muhammadiyah Palembang Tahun 2010. Syifa Medika, 2012; 3 (1): 1-11.

9. Mayasari, D. Hubungan Respon Imun dan Stres dengan Tingkat Kekambuhan Demam Tifoid pada Masyarakat di Wilayah Puskesmas Colomadu Karanganyar. Berita Ilmu Keperawatan. 2009; 2 (1): 13-18.

10. Pramitasari, O.P. Faktor Resiko Kejadian Penyakit Demam Tifoid pada Penderita yang Dirawat di Rumah Sakit Umum Daerah Ungaran, Jurnal Kesehatan Masyarakat. 2013; 2 (1): 1-10.

11. Musnelina, L., Afdhal, A.F., Gani, A. and Andayani, P. Pola Pemberian Antibiotika Pengobatan Demam Tifoid Anak di Rumah Sakit Fatmawati Jakarta Tahun 2001-2002. Makara Kesehatan, 2004; 8 (1): 27-31.

12. Soedarmo, S.S.P., Garna H., Hadinegoro S.R., and Satari H.I. Buku Ajar Infeksi Pediatri dan Tropis. Jakarta: Badan Penerbit IDAI. 2010.
13. Pickering Larry K, Clearly Thomas G. Infection of The Gastrointestinal Tract. In: Krugman's Infectious Diseases of Children. $11^{\text {th }}$ Edition. Philadelphia. Mosby: p.212-218. 2004.

14. Hapsari, I.S., and Mutmainah, N. Evaluasi Penggunaan Antibiotika Pada Pasien Dewasa Demam Tifoid di Instalasi Rawat Inap RSUD Dr Moewardi Pada Tahun 2014. Surakarta: Fakultas Farmasi Universitas Muhammadiyah Surakarta. 2014.

15. Kemenkes R.I. Pedoman Umum Penggunaan Antibiotik. Jakarta: Kementerian Kesehatan Republik Indonesia. 2011.

16. Ajum, Hermina Aprilita. Evaluasi kerasionalan penggunaan antibiotika pada pasien anak dengan demam tifoid berdasarkan kriteria Gyssens di Instalasi Rawat Inap RSUD Panembahan Senopati Bantul Yogyakarta periode Januari-Desember 2013. Yogyakarta: Universitas Sanata Dharma. 2015.

17. Kristyasari, A.W. Evaluasi Penggunaan Antibiotik Pada Pasien Pediatrik Demam Tifoid Dengan Metode Gyssens Di RSUD Kota Yogyakarta Tahun 2016-2017. Yogyakarta: Universitas Sanata Dharma. 2019.

18. Butler, T. Treatment of Typhoid Fever in the 21st Century: Promises and Shortcomings. New Jersey: Department of Microbiology and Immunology, Ross University School of Medicine. 2011.

19. Sidabutar, S. and Satari H. I. Pilihan Terapi Empiris Demam Tifoid pada Anak: Kloramfenikol atau Seftriakson. Jurnal Sari Pediatri. 2010; 11 (6): 434-439.

20. Setiawan, S. Evaluasi Rasionalistas Penggunaan Antibiotik di Rawat Inap Bagian Penyakit Dalam Rumah Sakit Umum PKU Muhammadiyah Bantul. Yogyakarta: Fakultas Kedokteran dan Ilmu Kesehatan, Universitas Muhammadiyah Yogyakarta. 2015. 